The Use of an Unstressed Extra-Metrical Syllable to Carry the Rime Author(s): G. C. Moore Smith

Source: The Modern Language Review, Vol. 15, No. 3 (Jul., 1920), pp. 300-303

Published by: Modern Humanities Research Association

Stable URL: http://www.jstor.org/stable/3714811

Accessed: 31-12-2015 16:03 UTC

Your use of the JSTOR archive indicates your acceptance of the Terms \& Conditions of Use, available at http://www.jstor.org/page/ info/about/policies/terms.jsp

JSTOR is a not-for-profit service that helps scholars, researchers, and students discover, use, and build upon a wide range of content in a trusted digital archive. We use information technology and tools to increase productivity and facilitate new forms of scholarship. For more information about JSTOR, please contact support@jstor.org. 
The odd form whatez, which Osgood has wrongly taken for a variant of watz, has nothing to do with 'was.' It is simply a scribe's blunder for hatez (bids), with $w$ added from the watz under it. The sense seems to call for a semicolon after datez and a comma after hatez.

North Haven,

Edwin H. TutTLE.

ConN., U.S.A.

\section{The Use of an Unstressed Extra-Metrical Syllable to Carry THE RIME.}

The late Dr Schipper in his History of English Versification (p. 275) discusses what he calls the Unaccented Rhyme and the AccentedUnaccented Rhyme-both of which he remarks to be common in Wyatt. He illustrates the first by the couplet

With horrible fear, as one that greatly dreadleth,

A wrongful death, and justice alway seek eth :

the second by

So chanced me that every passion

Whereof if that I laugh at any sealson

with which we may compare a couplet of Spenser's (Shepherd's Calendar, II, 43, 44):

Comes the breme Winter with chamfred browes

Full of wrinckles and frostie furr|owes.

It may be worth while to point out that the latter form of rime is especially common in Peele. The following examples are taken from Mr Bullen's edition. The abnormal line is sometimes the first in the couplet.

\section{Arraignment of Paris:}

Accounts more honour done to her this day

Than ever whilom in these woods of $I \mid$ da.

$$
\text { I, i, 173, } 174 \text {; cp. 203, } 204 .
$$

But, pray you, tell me, Juno, was it so,

As Pallas told me here the tale of Ech|o.

$$
\text { II, i, 1, } 2 .
$$

If then this prize be but bequeath'd to beau|ty,

The only she that wins this prize am I.

II, i, 58, 59; cp. v, i, 165, 166 ; Tale of T. 103, 104.

Shepherd abash not, though at sudden thus

Thou be arrived by ignorance among | us.

II, i, 106, 107.

If, as my office bids, myself first brings

To my sweet madam these unwelcome tid/ings.

$$
\text { III, ii, 85, } 86 .
$$


As what was then our general agree/ment

To stand unto thy will be now content. III, ii, 103, 104 ; cp. IV, i, 181, 182 ; 207, 208.

And crave this grace of this immortal senlate,

That ye allow the man his advocate.

$$
\text { IV , i, 45, 46; cp. 197, } 198 ; 223,224 ; 259,260 .
$$

That may not be : the laws of heaven deny

A man to plead or answer by attoriney.

$$
\text { Ir, } \mathrm{i}, 4 \overline{7}, 48 .
$$

Nay gods I trow you are like to have great silence,

Unless this parrot be commanded hence.

But ladies under favour of your age,

$$
\text { IV, } i, 5 \overline{7}, 58 .
$$

Howe'er it be, you play upon the vant age.

$$
\text { IV, i, 221, 222. }
$$

Behold I take thy. dainty hand to kiss

And with my solemn oath confirm my promise.

$$
\text { v, i, 39, } 40 .
$$

\section{Edward I:}

Returning weary home from out the Holy Land

A Welshman shall be king and govern merry England.

$$
\text { II, 263, } 264 .
$$

By Gis, fair lords, ere many days be past,

England shall give this Robin Hood bis break|fast.

$$
\mathrm{x}, 109,110 .
$$

Nicholson's remark: 'Strike out "Hood." This restores metre...' is a proof that the peculiarity of Peele's verse now illustrated required to be pointed out.

\section{David and Bethsabe :}

Open, I say, and, as you open, sing

Welcome, fair Bethsabe, king David's darling.

Tale of Troy:

So honoured for his royal progeny,

Blest in his queen, his offspring and his coun|try.

Of wit and wisdom such as might suffice

To venter on the highest piece of ser/vice.

A dreadful dream, and, as it did hefall

To Priam's Troy a dream deadly and fat|al.

Then was the time when Flora dight with flowers

Like Iris in her pride and parti-collours.

So Peleus' valiant son, the great Achililes, That lately with the Grecians took the seas, Restrain'd awhile in habit of a wom|an, Unworthy wrong done to so brave a man. 
The flower of Greece, and armies all by this, For want of wind, had hover'd long in Aullis.

$233,234$.

And all for love of the unconstant Cress/ed

T'encounter with th' unworthy Diomed.

$282,283$.

Where he may prove his strength, and storming thus

He lights upon Achilles' friend Patroc|lus.

306,307 ; cp. $444,445$.

And having thus perform'd this piece of trea|son,

He triumphs in the spoils of Priam's son.

Similarly, in a quatrain of The Praise of Chastity:

Believe me, to contend 'gainst armies roy|al

To praise the triumph not so special.

Peele's text is often corrupt, but clearly the feature here pointed out is too frequent to be explained in any other way than as due to the author.

I find no examples of the phenomenon in the Spanish Tragedy nor in Greene. But I have come across these in Selimus (ed. Grosart):

That begs the common soldiers' suffrages

It would the more increase their insolent/ness. 820,822 (in a quatrain).

Your flashing buffets and outrageous blows

Shall soon be wrecked upon the sandy shallows. 1768,1770 (in a quatrain).

The last passage, as has been pointed out to me by $\mathrm{Mr}$ Walter Worrall, is a reproduction of Spenser's $F$. Q. III, iv, 9 :

Though thy strong buffets and outrageous blowes

On the rough rocks, or on the sandy shaljlowes.

In Donne I have noticed in The Storm:

With a salt dropsy clogg'd and all our tack|lings

Snapping like too-too-high-stretch'd treble strings.

And in Sat. I :

And wily statesmen which teach how to tie

The sinews of a city's mystic bod|y.

In Jonson in Epigram $C X I V$ :

Hath changed his soul, and made his object you ;

Where, finding so much beauty met with vir|tue. 
In Fletcher, verses to Sir Robert Townsend, prefixed to The Faithful Shepherdess:

Yet according to my talent

A poor Shepherd I have sent.

$8,10$.

G. C. Moore Sмith.

ShEFFIELD.

\section{IzaAK WaLton and John Donne.}

About three quarters through the first chapter of Walton's Compleat Angler, will be found a passage which in the first edition (1653) runs as follows:

'And since I have your promise to hear me with patience, I will take a liberty to look back upon an observation that hath been made by an ingenuous and learned man, who observes that God hath been pleased to allow those whom he himselfe hath appointed, to write his holy will in holy Writ, yet to express his will in such Metaphors as their former affections or practise had inclined them to ; and he brings Solomon for an example, who before his conversion was remarkably amorous, and after by Gods appointment, writ that Love-Song betwixt God and his Church.'

The passage slightly expanded and modified appears in all later editions.

I cannot find that anyone has identified Walton's 'ingenuous (sc. 'ingenious') and learned man.'

In reading the admirable selection of passages from Donne's Sermons lately edited for the Clarendon Press by Mr L. Pearsall Smith, I came across this passage (pp. 24-26) from Donne's sermon preached before Queen Anne on Dec. 14th, 1617, and published as Sermon XVIII in Donne's XXVI Sermons (1660):

'As the Prophets and the other Secretaries of the Holy Ghost...do for the most part retain...some air of their former professions...ever inserting into their writings some phrases, some metaphors, some allusions, taken from that profession which they had exercised before...according to this Rule too, Salomon, whose disposition was amorous, and excessive in the love of women, when he turn'd to God, he departed not utterly from his old phrase and language, but...he conveyes all his loving approaches and applications to God, and all Gods gracious answers to his amorous soul, into songs, and Epithalamians.'

It can hardly be doubted after this that Walton's 'ingenuous and learned man' was Donne. It is to be noted however that Donne's sermon was not published till 1660 . Had Walton access to it in MS.? Was he assisting John Donne the younger to prepare this 1660 volume for the press? Or had the elder Donne repeated this thought in some sermon which Walton had heard from his lips?

SHeFFIELD.

G. C. Moore Smith. 